\title{
Co-localization of islet amyloid polypeptide and insulin in the B cell secretory granules of the human pancreatic islets
}

\author{
A. Lukinius ${ }^{1}$, E. Wilander ${ }^{1}$, G.T. Westermark ${ }^{2}$, U. Engström ${ }^{3}$ and P. Westermark ${ }^{2}$ \\ ${ }_{1}^{1}$ Department of Pathology, University Hospital, Uppsala, \\ ${ }^{2}$ Department of Pathology, University Hospital, Linköping, and ${ }^{3}$ Ludwig Institute of Cancer Research, Uppsala Branch, Uppsala, Sweden
}

\begin{abstract}
Summary. Islet amyloid polypeptide is a novel 37 amino-acidresidues polypeptide which has been isolated from amyloid deposits in an insulinoma, and in human and cat islets of Langerhans. The molecule has $46 \%$ homology with the calcitonin gene-related peptide. Light microscopy examination of the pancreas shows that islet amyloid polypeptide immunoreactivity is restricted to the islet B cells. The present study utilized a rabbit antiserum against a synthetic peptide corresponding to positions 20-29 of islet amyloid polypeptide, a sequence without any amino-acid identity with calcitonin gene-related peptide. By applying the immunogold technique at the ultra-
\end{abstract}

structural level, it was shown that both insulin and islet amyloid polypeptide immunoreactivity occurs in the central granular core of the human B cell secretory granules, while the A cells remain unlabelled. The demonstration that islet amyloid polypeptide is a granular protein of the B cells may indicate that it is released together with insulin. Further studies are necessary to evaluate the functional role of islet amyloid polypeptide.

Key words: Islet amyloid polypeptide, Pancreatic islets, B cells, Ultrastructure, Immunocytochemistry.
Isolation and chemical characterization of amyloid deposits from a human insulinoma has revealed the existence of a previously unknown peptide designated Islet (or Insulinoma) Amyloid Polypeptide (IAPP) [1, 2]. Subsequently, it was shown that the amyloid fibrils in the islets of Langerhans, which is a most characteristic morphological finding in Type 2 (non-insulin-dependent) diabetes mellitus, has identical chemical composition $[3,4]$. IAPP is also the constituent of the fibrils in feline islet amyloid, which is mainly seen in old diabetic cats $[2,3]$. IAPP consists of 37 amino-acid residues and has $46 \%$ identity with the neuro-peptide calcitonin gene-related peptide (CGRP) [2]. The function of IAPP is not yet known.

Light microscopic examination of the human pancreas demonstrates that IAPP and insulin antisera label identical islet cells $[2,4-6]$. The aim of the present study was to clarify the subcellular localization of IAPP in the normal human pancreatic islet B cells.

\section{Subjects, materials and methods}

\section{Tissues}

Apparently normal human pancreata were obtained from three patients (two males, 45 and 70 years old and one female, 72 years old) undergoing pancreatic resection due to carcinoma. The material used was taken from a non-affected part of the pancreas. The patients did not suffer from any metabolic disease and no amyloid was found in any of the three pancreata. For light microscopy the samples were fixed in $4 \%$ formaldehyde, dehydrated in ethanol and embedded in paraffin. For electron microscopy the samples were (a) fixed in $2 \%$ glutaraldehyde for $6 \mathrm{~h}$ at $+20^{\circ} \mathrm{C}$, postfixed in $1 \%$ osmium tetroxide for $1 \mathrm{~h}$ at $+20^{\circ} \mathrm{C}$ and embedded after a conventional protocol in Agar 100 (an epoxy resin of Epon type, Agar Aids Ltd, Stansted, Essex, UK) (7), (b) fixed in $4 \%$ paraformaldehyde $/ 0.5 \%$ glutaraldehyde for $6 \mathrm{~h}$ and embedded as a), or (c) fixed in $4 \%$ paraformaldehyde $/ 0.5 \%$ glutaraldehyde for $2 \mathrm{~h}$ at $+4^{\circ} \mathrm{C}$, dehydrated in $50-95 \%$ ethanol fol-

Fig. 1. Light microscopical (LM) view of the pancreas where an islet of Langerhans is labelled with anti-IAPP antisera. Bar $=50 \mu \mathrm{m} ; \times 410$

Fig. 2. LM view of the pancreas where an islet of Langerhans is labelled with anti-insulin antisera. Fig. 1 and Fig. 2 show the same islet in consecutive sections. $\mathrm{Bar}=50 \mu \mathrm{m} ; \times 410$

Fig. 3. Two B cells with their typical vesicular granules containing angular or rodlike, crystalline cores (arrows, see also Fig.4) and one A cell in the lower left corner. The A cell granules are round with a highly electrondense core surrounded by an eccentric halo (arrowhead, see also Fig. 5). IAPP ( $5 \mathrm{~nm}$ gold particles) is demonstrated exclusively in the B cell granules together with insulin $(15 \mathrm{~nm}$ gold particles). Neither of these peptides were found anywhere else in the islets but in the B cell granules. Bar $=0.3 \mu \mathrm{m} ; \times 43300$

Fig.4. Detail of a B cell with its granules filled with labels visualizing IAPP ( $5 \mathrm{~nm}$ gold particles, arrow) and insulin $(15 \mathrm{~nm}$ gold particles, arrowhead). Bar $=0.2 \mu \mathrm{m} ; \times 76800$ 

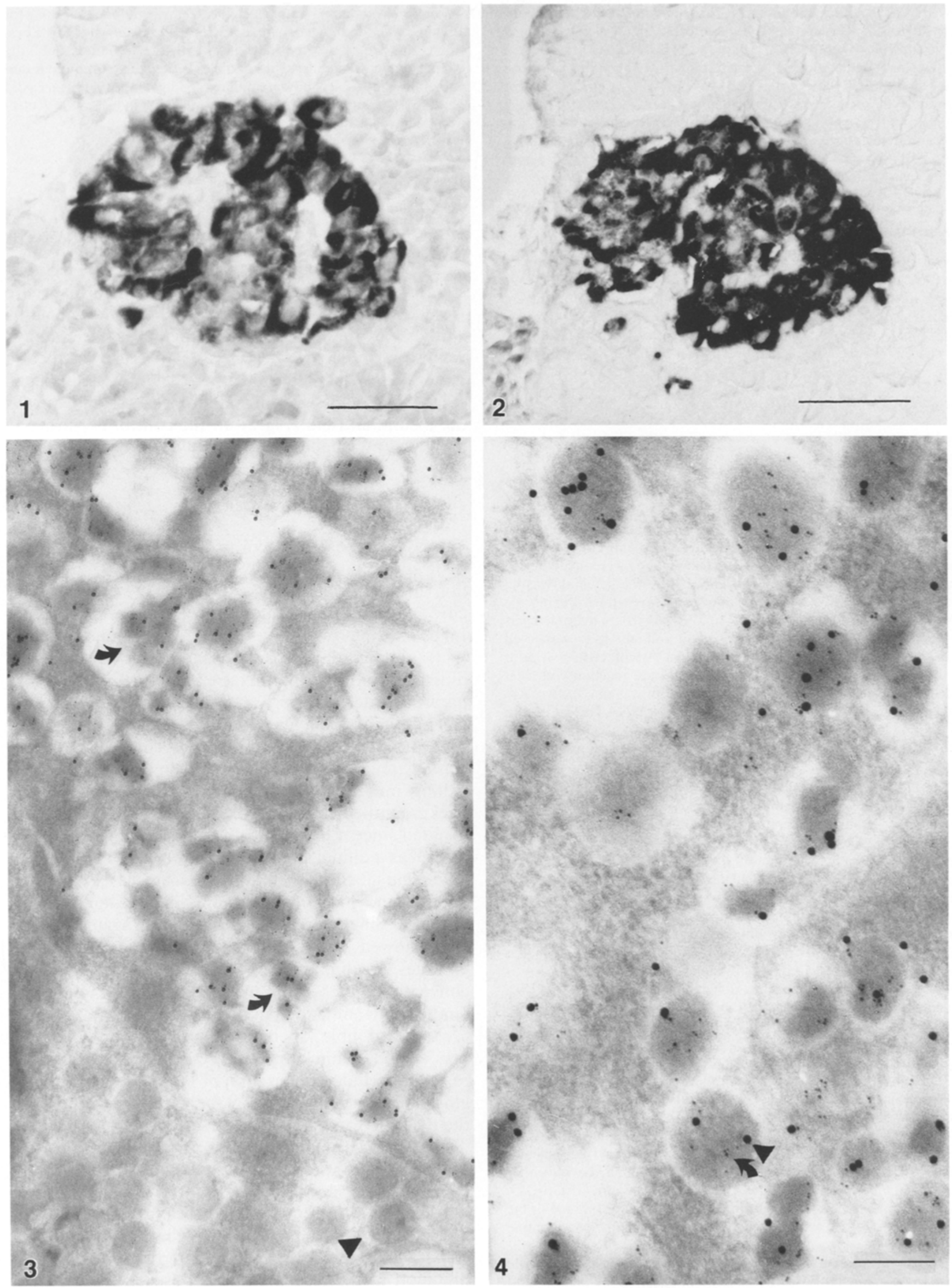
lowed by embedding in Lowicryl K4M (Agar Aids Ltd.). During the dehydration step the temperature was lowered from $+4^{\circ} \mathrm{C}$ to $-10^{\circ} \mathrm{C}$. Infiltration and photopolymerization (UV-light, $360 \mathrm{~nm}$ ) took place at $-10^{\circ} \mathrm{C}$ [8-12]. In all three electron microscopy embedding protocols a $0.1 \mathrm{~mol} / 1$ cacodylate buffer, $\mathrm{pH} 7.2$, containing $0.1 \mathrm{~mol} / 1$ sucrose was used. Levels in the blocks containing islets of Langerhans were found with the help of semithin sections stained with toulidine blue and ultrathin sections were cut with a diamond knife on an LKB UItrotome No IV (LKB-Produkter AB, Bromma, Sweden) and placed on formvar-coated nickel grids.

\section{Antisera}

A synthetic peptide, corresponding to positions 20-29 of human IAPP (IAPP $20-29)$ was produced. The molecule was linked to key-hole limpet haemocyanin $(\mathrm{KLH})$, mixed with Freund's complete adjuvant and injected in rabbits every third week for 7 months, whereafter antiserum (AA 90) was obtained. Guinea pig antiserum to insulin was purchased from Dakopatts (Santa Barbara, Calif, USA).

\section{Immunocytochemistry}

Light microscopy. Sections of the paraffin-embedded material were deparaffinised, treated with $0.3 \%$ hydrogen peroxide and incubated over-night with antiserum to $\operatorname{IAPP}_{20-29}$ (AA 90), diluted 1:400 in $0.05 \mathrm{~mol} / 1$ Tris- $\mathrm{HCl}$ buffer, $\mathrm{pH} 7.2$, with $0.15 \mathrm{~mol} / 1 \mathrm{NaCl}$ (TBS), or antiserum against insulin, diluted 1:1000 in TBS, in a moist chamber at $+20^{\circ} \mathrm{C}$. Serial dilution tests determined the optimal concentration of the antisera. As intermediate antibodies sheep anti-rabbit IgG and sheep anti-guinea pig IgG was used. The sections were incubated in the PAP-complex, diluted 1:80 in TBS, before the labelling was visualized by using 30\% 3,3-diaminobenzidine-tetrahydrochloride (DAB) (Sigma, St. Louis, MO, USA) in TBS with $0.02 \%$ hydrogen peroxide as chromogen [13]. Normal guinea pig and rabbit sera were used in the control experiments. Absorption of AA 90 with IAPP20-29 prior to the immunolabelling procedure abolished the reaction with islet $\mathrm{B}$ cells, while absorption with KLH and insulin was uneffective. Absorption of insulin antiserum with recombinant DNA human insulin (Humulin; Kabi-Vitrum, Stockholm, Sweden) also abolished the reaction with islet $B$ cells, while absorption with $\mathrm{IAPP}_{20-29}$ was ineffective.

Electron microscopy. Immunocytochemical labelling for electron microscopy was done after a protocol of De Mey [14] modified by Lukinius et al. [7]. Sections from all three fixation/embedding protocols were used and etching in saturated sodium-metaperiodate (Merck, Darmstadt, FRG) for 0, 3, 5 and 10 min was performed. After careful rinsing in water, the sections were blocked with normal goat serum (National Veterinary Institute, Uppsala, Sweden) diluted 1:20 in TBS with $0.1 \%$ BSA (Bovine serum albumine type V, Sigma, St. Louis, MO, USA) for $30 \mathrm{~min}$ at $+20^{\circ} \mathrm{C}$. The sections were drained and incubated with antiserum against $\mathrm{IAPP}_{20-29}$ diluted 1:800 in TBS-0.1\% BSA at $+4^{\circ} \mathrm{C}$ over-night, drained again and incubated for $2 \mathrm{~h}$ at $+20^{\circ} \mathrm{C}$ with antiserum against insulin (1:1000 in TBS- $0.1 \%$ BSA). After careful rinsing in TBS containing $0.1 \%, 0.2 \%$ and finally $1.0 \% \mathrm{BSA}$, the sections were incubated for $2 \mathrm{~h}$ at $+20^{\circ} \mathrm{C}$ with goat anti-rabbit IgG conjugated to $5 \mathrm{~nm}$ colloidal gold (GAR-G5, Janssen Pharmaceutica N.V., Beerse, Belgium) diluted 1:20 in TBS, pH 8.2, with 1\% BSA. After draining, the grids were incubated with goat anti-guinea pig IgG conjugated to $15 \mathrm{~nm}$ colloidal gold (GAGp-G15, Janssen Pharm.), diluted $1: 20$ in TBS, pH 8.2 , with $1 \%$ BSA for $2 \mathrm{~h}$ at $+20^{\circ} \mathrm{C}$. Finally, the grids were rinsed and counterstained with uranyl acetate and Reynolds lead citrate. Grids were also single-labelled with either IAPP $_{20-29}$ antiserum/GAR-G15 or insulin antiserum/GAGp-G15. As control, incubation with the primary antiserum was omitted or the primary antiserum was replaced by the homologous non-immune serum. Otherwise sections were treated as described above.

To obtain optimal results, all buffers were passed through sterile filters (pore diameter $0.20 \mu \mathrm{m}$ ) and any aggregates in the protein- and gold/protein solutions were pelleted by centrifugation at $2000 \times \mathrm{g}$ for $15 \mathrm{~min}$. Ealier double-labelling experiments have shown that the best results are acquired when incubation with the secondary antibody conjugated to the smallest gold particles is done first, followed by incubation with the secondary antibody conjugated to the bigger gold particle [7]. Examination of the results was done in a Jeol $100 \mathrm{C}$ electron microscope.

\section{Results}

\section{Light microscopy}

Examination of routinely embedded paraffin sections, stained with haematoxylin/eosin, confirmed that there were no abnormalities in the pancreata used in this study. With the peroxidase anti-peroxidase method, it was shown that the $\mathrm{IAPP}_{20-29}$ antiserum labelled a major cell population in the islets of Langerhans (Fig.1). The same labelling pattern was also shown with the insulin antisera (Fig.2). In the control experiments there was no labelling with any of the two antisera.

\section{Electron microscopy}

The conventional protocol with fixation in glutaraldehyde and osmium tetroxide followed by $100 \%$ dehydration and embedding in epoxy resin gave a very unspecific and sparse labelling when IAPP antisera was used. Likewise, the result was poor when paraformaldehyde/glutaraldehyde fixation and epoxy resin embedding was used. The mild fixation for $2 \mathrm{~h}$ at $+4^{\circ} \mathrm{C}$ in $4 \%$ paraformaldehyde $/ 0.5 \%$ glutaraldehyde, followed by embedding in the hydrophilic low temperature embedding media Lowicryl K4M, preserved the IAPP antigenicity much better and was used in the study. The labelling intensity was high and there was almost no background. Etching in sodium-metaperiodate was avoided since it had a negative effect on the specificity as well as a diminishing effect on the labelling.

Single labelling with antisera against IAPP showed specific and prominent immunoreaction in the B cell granules. Single labelling with antisera against insulin also showed specific immunoreaction in the Bcell granules. Insulin antigenicity was preserved both in the conventional embedded material as well as in the low temperature embedded material.

In the double labelling experiments the gold markers (5 and $15 \mathrm{~nm}$ respectively) used for identification of the subcellular localization of IAPP and insulin were almost exclusively found in the secretory granules of the B cells. Mostly, there was an obvious co-localization of IAPP and insulin immunoreactivity in the same granules. The gold-particles were predominantly localized to the electron-dense central core of the granules leaving the peripheral electron lucent space unlabelled (Figs. 3 and 4). Any noteworthy unspecific background labelling that could interfere with the interpretation of the results was not observed. The A cells 


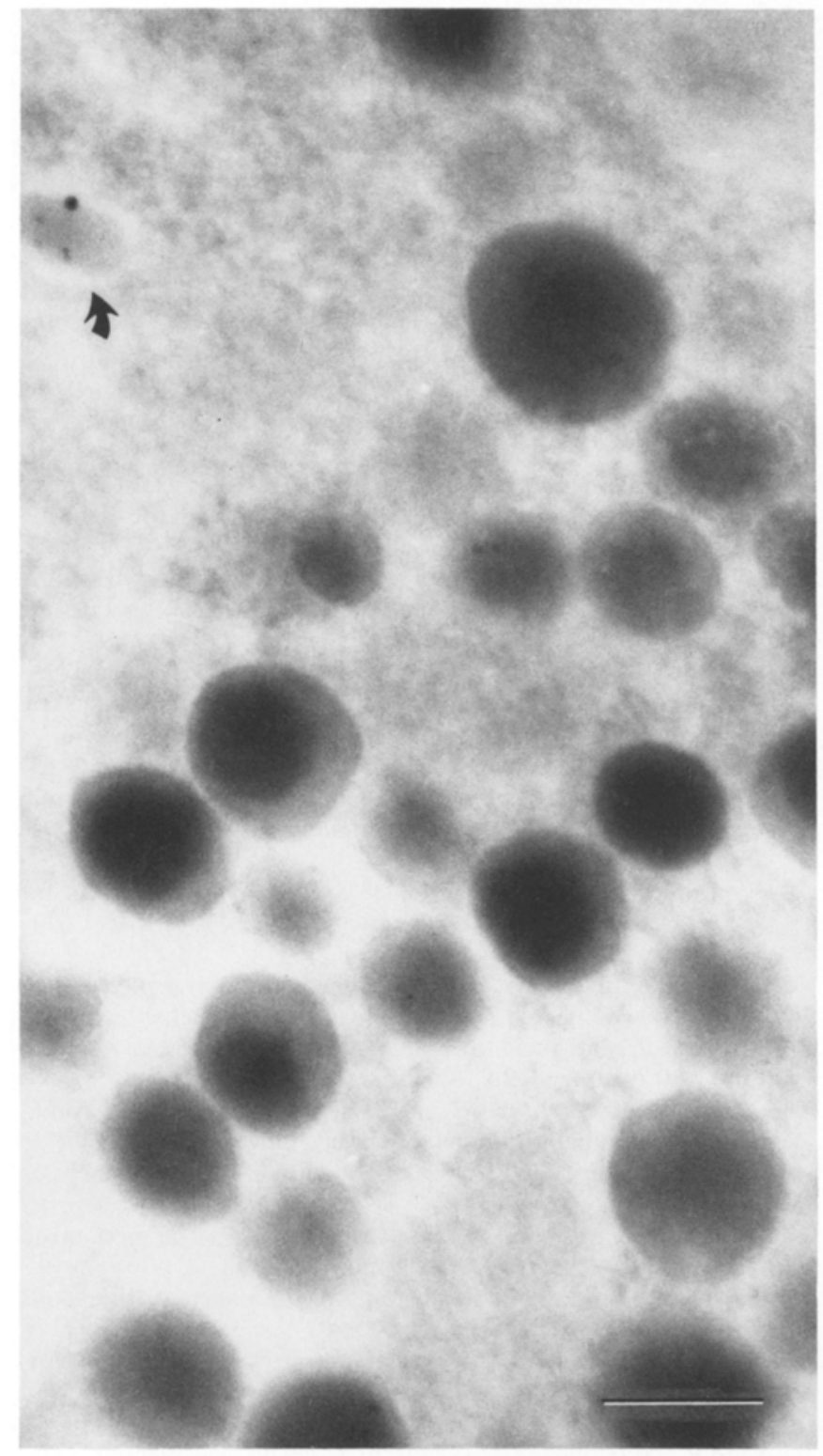

Fig.5. Detail of an A cell completely lacking any label for IAPP or insulin. Note the B cell granule in the upper left corner containing labels for both IAPP and insulin (arrow). Bar $=0.2 \mathrm{um} ; \times 87000$

were unreactive to both IAPP and insulin antisera (Fig. 5).

Light microscopical experiments with the PAP technique, and electron microscopical experiments with the immuno-gold technique, confirm that there is no crossreactivity between the secondary antibodies. In the control experiments where the primary antisera were omitted no labelling occured.

\section{Discussion}

The functional significance of IAPP is unknown. However, several facts indicate that IAPP possesses a hormonal function, namely: (a) the $46 \%$ amino-acid homology with CGRP, a recently identified neuropep- tide that is present in certain restricted areas of the central and peripheral nervous system $[15,16]$, (b) its occurrence in the islet $\mathrm{B}$ cells and co-localization with insulin in the secretory granules, (c) the amyloid in the $C$ cell tumour of the thyroid gland consists of a calcitonin-related protein, probably procalcitonin [17], (d) IAPP is expressed as a 89 amino-acid residue molecule consistent with a preprohormone (C. Betsholtz et al. to be published) and (e) IAPP has been shown to be a potent inhibitor of both basal and insulin-stimulated rates of glycogen synthesis in stripped rat soleus muscle in vitro [18]. It is possible that IAPP is co-released with insulin from the $B$ cells on stimulation.

The findings in the present investigation clearly indicate that the IAPP immunoreactivity in human B cell granules is restricted to the electron-dense core. In a previous electron microscopic study performed on cat islet B cells, IAPP immunoreactivity was localized to the outer, translucent zone of the secretory granules [5]. This discrepancy cannot be explained at present but species differences may exist, and fixation and processing can result in redistribution of soluble proteins which would explain the differences between the present and previous results. The antisera used in both the studies had also been raised to different parts of the IAPP molecule. In the present study we used antiserum to IAPP $_{20-29}$, while in the previous study antiserum to IAPP $_{7-17}$ was employed. While the sequence of IAPP $_{20-29}$ is unique to IAPP, IAPP $7-17$ is $>50 \%$ identical to CGRP [2]. However, at the light microscopical level the two different IAPP antisera gave identical staining of islets in human pancreas.

Recently, it has been shown that the human B cells display chromogranin immunoreactivity [19]. The chromogranins comprise a family of acidic high molecular weight polypeptides, originally isolated from the granules of the adrenal medulla [20-23]. The levels of chromogranin in serum are elevated in patients with a great variety of neuroendocrine tumours and the chromogranins are regarded as putative peptide hormones [19, 24]. Apparently the B cell granules are the storage site of several peptides in addition to C-peptide and insulin. Although speculative, it is reasonable to assume that at B cell granular exocytosis, a spectrum of peptide molecules are released into the circulation. Such a theory has major clinical implications since, from the morphological point of view, Type 1 (insulin-dependent) diabetes mellitus is a disease characterized by pronounced B cell deficiency [25-29]. This means that deficiency of substances other than insulin may also be of some significance for the metabolic disturbances and late complications occurring in many diabetic individuals.

IAPP was originally identified by chemical analysis of amyloid from a human insulinoma, and subsequently from insular amyloid [1-4]. Antiserum to IAPP reacts both with $B$ cells and the islet amyloid deposits $[5,6]$. In Type 2 diabetes, IAPP immunoreactivity in the B cells is diminished while IAPP is deposited as 
amyloid fibrils in the islets [6]. Islet amyloid deposits occur in addition to humans in a limited number of mammalian species e.g. monkeys [30] and cats [31], in association with a form of diabetes which resembles human Type 2 diabetes. This indicates that the ability of IAPP to polymerize to amyloid is associated with the development of Type 2 diabetes. More information about species variations in the amino acid sequence and metabolic pathways of IAPP may increase the knowledge about the pathogenesis of Type 2 diabetes.

Acknowledgements. Supported by the Swedish Medical Research Council (Projects No.6817 and 5941), the Research Fund of King Gustaf V, the Nordic Insulin Fund and the Louis-Hansens Memorial Fund. This work was presented in a poster, SCANDEM-88, June 6-8, 1988, Aarhus, Denmark.

\section{References}

1. Westermark P, Wernstedt C, Wilander E, Sletten K (1986) A novel peptide in the calcitonin gene related peptide family as an amyloid fibril protein in the endocrine pancreas. Biochem Biophys Res Commun 140: 827-831

2. Westermark $P$, Wernstedt $C$, Wilander $E$, Hayden $D, O^{\prime} B$ rien $T$, Johnson K (1987) Amyloid fibrils in human insulinoma and islets of Langerhans of the diabetic cat are derived from a neuropeptidelike protein also present in normal islet cells. Proc Natl Acad Sci USA $84:$ : 3881-3885

3. Westermark P, Wernstedt C, O'Brian TD, Hayden DW, Johnson KH (1987) Islet amyloid in type 2 human diabetes mellitus and adult diabetic cats contains a novel putative polypeptide hormone. Am J Pathol 127: 414-417

4. Cooper GJS, Willis AC, Clark A, Turner RC, Sim RB, Reid KBM (1987) Purification and characterization of a peptide from amyloid-rich pancreases of Type 2 diabetic patients. Proc Natl Acad Sci USA 84: 8628-8632

5. Johnson KH, O'Brian TD, Hayden DW, Jordan K, Ghobrial HKG, Mahoney WC, Westermark P (1988) Immunolocalization of islet amyloid polypeptide (IAPP) in pancreatic beta cells by means of peroxidase-antiperoxidase (PAP) and protein A-gold techniques. Am J Pathol 130: 1-8

6. Westermark P, Wilander E, Westermark G, Johnson K (1987) Islet amyloid polypeptide-like immunoreactivity in the islet $B$ cells of Type 2 (non-insulin-dependent) diabetic and nondiabetic individuals. Diabetologia 30: 887-892

7. Lukinius A, Ericsson JLE, Lundqvist M, Wilander E (1986) Ultrastructural localization of serotonin and polypeptide YY (PYY) in endocrine cells of the human rectum. J Histochem Cytochem 34: 719-726

8. Armbruster B, Carlemalm E, Chiovetti R, Garavito RM, Hobot JA, Kellenberger E, Villinger W (1982) Specimen preparation for electron microscopy using low temperature embedding resins. J Microsc 126: 77-85

9. Carlemalm E, Garavito RM, Villiger W (1982) Resin development for electron microscopy and an analysis of embedding at low temperature. J Microsc 126: 123-143

10. Carlemalm E, Villiger W, Hobot JA, Acetarin JD, Kellenberger E (1985) Low temperature embedding with Lowicryl resin: two new formulations and some applications. J Microse 140: 55-63

11. Kellenberger E, Carlemalm E, Villiger W, Roth J, Garavito RM (1980) Low denaturation embedding for electron microscopy of thin sections. Chemische Werke Lowi, Waldkraiburg, FRG

12. Roth J, Bendayan M, Carlemalm E, Villiger W, Garabito RM (1981) Enhancement of structural preservation and immunocytochemical staining in low temperature embedded pancreatic tissue. J Histochem Cytochem 29: 663-671
13. Sternberger LA (1979) Immunocytochemistry, second edn. John Wiley \& Sons, New York Chichester Brisbane Toronto

14. De Mey JR (1983) The preparation of immunoglobulin gold conjugates (IGS reagents) and their use as markers for light and electron microscopic immunocytochemistry. In: Cuello AC (ed) Immunohistochemistry, Vol 3. John Wiley \& Sons, Chichester New York Brisbane Toronto Singapore, pp 347-372

15. Rosenfeld MG, Mermod JJ, Amara SG, Swanson LW, Sawchenko PE, Rivier J, Vale WW, Evans RM (1983) Production of a novel neuropeptide encoded by the calcitonin gene via tissue-specific RNA processing. Nature (Lond) 304: 129-135

16. Sternini C, Brecha N (1986) Immunocytochemical identification of islet cells and nerve fibres containing calcitonin gene-related peptide-like immunoreactivity in the rat pancreas. Gastroenterology 90: 1155-1163

17. Sletten K, Westermark P, Natvig JB (1976) Characterization of amyloid fibril proteins from medullary carcinoma of the thyroid. $J$ Exp Med 143: 993-998

18. Leighton B, Cooper GJS (1988) Pancreatic amylin and calcitonin gene-related peptide cause resistance to insulin in skeletal muscle in vitro. Nature 335: 632-635

19. Eriksson B (1988) Recent advances in the diagnosis and management of endocrine pancreatic tumors. Doctorial thesis. Acta Universitatis Upsaliensis No 160. Uppsala, Sweden

20. Blaschko H, Comline RS, Schneider FH, Silver M, Smith AD (1967) Secretion of chromaffin granule protein, chromogranin from adrenal gland after splenic stimulation. Nature (Lond) 215: $58-59$

21. Schneider FH, Smith AD, Winkler H (1967) Secretion from the adrenal medulla: evidence for exocytosis. Br J Pharmacol Chemother 31: 94-104

22. Cohn DV, Zaugerle R, Fisher-Colbrie R, Chu LCH, Elting JJ, Hamilton JW, Winkler H (1982) Sirnilarity of secretory protein I from parathyroid gland to chromogranin A from adrenal medulla. Proc Natl Acad Sci USA 79: 6056-6059

23. O'Connor DT, Burton D, Leonard J, Deftos LJ (1983) Chromogranin A: immunohistology reveals its universal occurrence in normal polypeptide-producing endocrine glands. Life Sci 33: $1657-1663$

24. Hutton JC, Davidsson HW, Peskararia M (1987) The mechanism of chromogranin A processing. Nature 325: 766

25. Gepts W (1965) Pathologic anatomy of the pancreas in juvenile diabetes mellitus. Diabetes 14: 619-633

26. Klöppel G, Drenck CR (1983) Immunozytochmemische Morphometrie beim Typ-I- und Typ-II-Diabetes mellitus. Dtsch Med Woschenschr 108: 188-189

27. Saito K, Yaginuma NI, Takahashi T (1979) Differential volumetry of A, B and D cells in the pancreatic islets of diabetic and nondiabetic subjects. Tohoku J Exp Med 129: 273-283

28. Stefan Y, Orci L, Malaisse-Lagae F, Perrelet A, Patel Y, Unger RH (1982) Quantitation of endocrine cell content in the pancreas of nondiabetic and diabetic humans. Diabetes 31: 694-700

29. Rahier J, Goebbels RM, Henquin JC (1983) Cellular composition of the human diabetic pancreas. Diabetologia 24: 366-371

30. Howard CF (1978) Insular amyloidosis and diabetes mellitus in Macaca nigra. Diabetes 27:357-364

31. Johnson KH, Hayden DW, O'Brien TD, Westermark P (1986) Spontaneous diabetes mellitus-islet amyloid complex in adult cats. Am J Pathol 125: 416-419

Received: 21 October 1988

and in revised form: 10 February 1989

Dr. A. Lukinius

Department of Pathology

University Hospital

S-75185 Uppsala

Sweden 